\section{NOVÝ WEBOVÝ PORTÁL A WEBOVÉ SLUŽBY PRO PREZENTACI MEZINÁRODNÍ KLASIFIKACE NEMOCÍ (MKN)}

\section{Michal Reimer, Anna Schlenker, Martin Komenda, Miroslav Zvolský}

\section{Anotace}

Mezinárodní statistická klasifikace nemocí a přidružených zdravotních problémů (MKN) je publikace založená na kodifikaci a klasifikaci onemocnění, poruch, príznaků či zranění, které jsou strukturovaně hierarchicky zařazené do jednotlivých kapitol a podkapitol v závislosti na typu onemocnění a je jim přiřazeno kódové označení usnadňující identifikaci pojmu ve struktuře.

MKN spravuje Světová zdravotnická organizace, která zajištuje vydávání nových verzí obsahujících opravy, vylepšení a doplnění tohoto klasifikátoru. MKN v současné 10. revizi slouží jako mezinárodní standard pro zaznamenávání (kódování) diagnóz. S přicházející 11. revizí, jejímž hlavním přínosem je rozšírení množství obsažených informací o jednotlivých pojmech například o detailnější popis onemocnění, stupnici závažnosti, popis symptomů či navrhované léčebné postupy se násobně zvyšuje potenciál této klasifikace jako informačního zdroje a nástroje pro práci se zdravotnickými daty.

Cílem naší práce je vytvoření nového webového portálu, který bude sloužit jako nástroj pro prezentaci informací obsažených v MKN a vlastní kódování. Tento portál by měl být schopen po prijijetí vstupních dat, at' už ve formě vyhledávaného názvu, kódu či názvu kapitol, klasifikaci prohledat a zobrazit veškeré nalezené výsledky - záleží pak jen na uživateli, do jaké míry specifikuje své vyhledávání. $\mathrm{S}$ touto specifikací by měla být uživateli nápomocná intuitivní realtimová nápověda, která př̀i vyhledávání doporučí pravděpodobný hledaný výraz. Cílem je získání co největšího množství informací k danému pojmu, které by zároveň díky struktuře a kódovému označením bylo možné jednoznačně zařadit a velmi snadno a intuitivně i zpětně získat dané informace při znalosti pouze tohoto kódu, což by velmi usnadnilo kódování klinických dat, s čímž se setkáváme např́iklad při vykazování zdravotní péče, vedení zdravotnických statistik, či uchovávání zdravotnických záznamů a dat.

\section{Klíčová slova}

\section{Mezinárodní klasifikace nemocí, zdravotnické klasifikátory}

\section{Mezinárodní klasifikace nemocí}

\section{1. Úvod}

MKN, celým názvem Mezinárodní statistická klasifikace nemocí a přidružených statistických problémů, v originále International Classification of Diseases and Related Health Problems - ICD je publikace, která kodifikuje systém klasifikace lidských onemocnění, poruch, příznaků s nemocemi souvisejících či okolností a situací, které k onemocnění vedly. Je postavená na rozřazení pojmů do jednotlivých kategorií a každému pojmu je následně přiřazen kód, který pak pojem reprezentuje a odpovídá zařazení v kategorii. Jedná se tedy o velmi jednoduchý, a zároveň přehledný systém, který je podrobněji popsán níže.

\subsection{Historie}

Počátek Mezinárodní klasifikace nemocí můžeme dohledat v tzv. Klasifikaci př́čin úmrtí z roku 1893, která byla vlastně její první verzí. Tato publikace byla postupně doplňována a rozšiřována v novějších verzích o další pojmy, které vycházely v intervalu s odstupem přibližně deseti let. $V$ roce 1948 převzala odpovědnost za publikaci Světová zdravotnická organizace WHO, pod kterou spadá její správa dodnes, a následně vydává v pořadí šestou verzi publikace, která jako první obsahovala kapitoly zabývající se i ne smrtelnými chorobami a pod novým názvem Mezinárodní statistická klasifikace nemocí, zranění a príčín smrti. Aktuálně používanou verzí publikace je její desátá verze MKN-10, která vyšla v roce 1993 (v ČR používána od roku 1994). Tato verze obsahuje přes 20 tisíc jednotlivých pojmů a je, na rozdíl od verzí předchozích, udržována aktuální, vedle celkové aktualizace na novou verzi, pomocí menších aktualizací, kde poslední vyšla v roce 2016 a v ČR byla přijata v roce 2018. Současně probíhají práce na jedenáctém vydání publikace MKN, jejíž vydání je očekávané během roku 2018. [3][4]

\subsection{Struktura MKN}

Aktuálně používaná verze MKN-10 obsahuje celkem dva takzvané svazky, kde první obsahuje strukturovaný seznam onemocnění, poruch a zranění a každému tomuto pojmu přiřazuje specifický kód, který je závislý právě na tom, kde se nalézá ve stromové struktuře tohoto seznamu, neboli též tzv. „Tabelární část“. Druhý svazek pak obsahuje instrukce pro záznam a kódování diagnóz. U různých vydání též bývá přičleněn svazek třetí, a to "Abecední seznam", kde můžeme najít veškeré pojmy seřazené abecedně a ne ve stromové struktuře (u pojmu je ovšem stále uveden kód z Tabelární části a tudíž je snadné pojem dohledat). Pokud se zaměříme na strukturu Tabelární části, pak na počátku je celý seznam rozčleněn na 22 hlavních kapitol. Rozdělení těchto kapitol je dle specifické části těla, kterou dané onemocnění postihuje a posledních pár kapitol, které se týkají specifických nezařazených případů jako napríklad „Onemocnění a zranění způsobená otravou“, „Externí př́ćiny morbidity a mortality“ či "Symptomy a príznaky abnormálních nálezů nezařazené v jiných kapitolách". Každá z těchto hlavních kapitol je zastoupena rrímskou číslicí l.-XXII. O úroveň níže se již dostáváme ke konkrétnímu rozčlenění, které je v kódu zastoupeno specifickým písmenem. Každá z hlavních kapitol má zadaný jaká písmena - a tudíž jaké kapitoly obsahuje, a tak i když rrímská číslice není součástí kódu, Ize dohledat, pod jakou hlavní kapitolu spadá. Na nižších úrovních seznamu jsou části kódu již pouze číselné (ve speciálních př́padech požadované specifikace se mohou objevit i speciální znaky - viz níže). V aktuální desáté verzi je maximální délka kódu, a tudíž možnost rozřazení kapitol, až sedm znaků. Toto nám oproti předchozím verzím, které umožňovaly znaků pouze pět, a u nejstarších pouze tři znaky, umožnilo značný nárůst množství obsažených informací. Historicky netknuta tak zůstává původní struktura kódu, která měla pouze tři znaky písmeno a dvě čísla - a postupně se pouze přidávalo množství pozic v kódu. Jak bylo řečeno, vyskytují se zde i specifické znaky namísto čísel (například hvězdička ${ }_{\text {" }}{ }^{* 1}$ či plus ${ }_{\text {" }}+$ ") které nám dále rozšiřují množství kombinací, které můžeme pro kód použít. Vyskytují se ale pouze na pozicích $4-7$ aby původní trojčlenná struktura zůstala stále stejná. Každá další podkapitola je tudiž určena jako další číslo či znak v kódu, dokud se nedostaneme až k samotnému pojmu.

\subsection{MKN-10}

V pořadí desátá verze, neboli MKN-10 vyšla v roce 1993 a v ČR se začala používat od roku 1994. Během následujících let prodělala další řadu menších úprav a uzpůsobení a to v letech 2004, 2010 a naposledy $v$ roce 2016. Pokud se zaměříme na hlavní verzi jako takovou, tak oproti predchozí deváté verzi přinesla další rozšíření kapacity klasifikátoru, a to konkrétně rozšíření kódu o šestou a sedmou pozici, čímž se navýšila možnost kombinací kódů z původních 17 tisíc na přibližně 150 tisíc. Dále pak například byly k hlavnímu svazku připojeny instruktážní manuály pro práci s klasifikátorem a tvorbou kódů pro usnadnění práce, připojeny kapitoly a pojmy zahrnující zákroky na pohotovostních centrech a specificky zaměřených soukromých klinikách, či 
pokus o zavedení kombinací kódů popisujících onemocnění se všemi jeho souvislostmi. V ČR se tato verze běžně používá pro kódování príčin smrti na tzv. „Listu o prohlídce zemřelého“, dále pak při vykazování zdravotní péče, vedení zdravotnické dokumentace a v nemocničních informačních systémech. [4]

\subsection{MKN-11}

MKN-11, která je aktuálně v procesu vývoje a její finální verze by měla vyjít během roku 2018, by měla celý systém značně rozšírit v mnoha směrech, nejvíce ovšem pravděpodobně v množství obsažených informací. Toto je dáno nejen pokrokem v oblasti informačních a webových technologií, které umožňují rychlé globální sdílení obrovského množství dat a informací, ale především změnou v postupu vývoje této verze. Vývoj této verze je poprvé v historii vývoje a správy MKN založen na otevřeném webovém prostředí, přes které odborníci po celém světě takto sestavují novou verzi tohoto klasifikátoru a není tak pouze výtvorem odborníků z organizace WHO. Tento proces je samozrejmě pod přísným dohledem a revizí, která zaručuje autenticitu výsledku. Druhým velkým krokem v nové verzi je rozšiření seznamu o popis jednotlivých pojmů, kde dříve byl obsažen pouze název onemocnění a jeho kódové označení. $V$ nové verzi by tento pojem měl být i definován pomocí specifických informací, takže kromě názvu by též obsahoval například stručný popis onemocnění, obsažená klíčová slova, popis projevů či symptomů či specifické léčebné postupy. Klasifikační systém by se tak mohl stát zdrojem velkého množství souvisejících odborných informací. Struktura kódu a hlavní rozčlenění kapitol by měla zůstat nepozměněna, na nižších úrovních z důvodu nárůstu objemu dat dojde pravděpodobně k zařazení podkapitol nových. [1]

\subsection{Využití MKN}

Klasifikace a její struktury se ve verzi MKN-10 využívá v nemocničních informačních systémech pro kódování, vedení a vykazování zdravotnické dokumentace. Dále se používá při tvorbě zdravotnických statistik výskytu nemocí a příčin úmrtí a následnou analýzu zdravotnických dat, čehož Ize využít například pro monitorování výskytu nemoci mezi specifickou skupinou pacientů a následných kroků za účelem prevence.

\section{Tvorba webového portálu pro prezentaci Mezinárodní klasifikace nemocí}

\subsection{Cíle a funkce webového portálu}

Cílem naší práce je vytvoření webového portálu, který by umožnil intuitivní a přehlednou práci $s$ informacemi obsaženými v publikaci MKN. Vytvoření prostředí, které by umožnilo velmi rychlou a jednoduchou navigaci skrze strukturu MKN a nalezení požadovaných pojmů v jednotlivých kategoriích. Tento výsledek bychom rádi rozšírili o další informace, které nejsou obsaženy v Tabelární části MKN. Například uvedení alternativního pojmenování onemocnění, které lze najít dle kódu v Abecedním seznamu $v$ třetím svazku (některé pojmy mají rozlišné názvy v Tabelárním a v Abecedním svazku) či rozšíření popisu kategorie o možné související pojmy či kapitoly a naopak pojmy, které do dané kapitoly nepatří, což by vedlo ke zpřesnění hledaného pojmu a možné bližší specifikace nemoci. Pokud se podíváme na vývoj verze $\mathrm{MKN}-11$, kde se přesně takovéto a mnohem hlubší zpřesnění popisu pojmu a rozšiřrení dostupných informací chystá, jednalo by se tak prakticky o jakýsi mezikrok mezi těmito verzemi a mohlo by nám to usnadnit prípravu a následnou migraci portálu na novou verzi MKN-11, pro kterou by byl portál cílově míněn - jako dostupný, přehledný a snadno ovladatelný nástroj pro prohlížení a správu odborných strukturovaných zdravotnických dat. Jedním z hlavních bodů naší práce je zaměření se na vyhledávání v publikaci pomocí vyhledávacího okna, které by bylo schopno vysoce intuitivní nápovědy a případné autokorekce při chybném zadání či překlepu hledaných názvů. Toto vyhledávání by právě bylo propojeno nejen s Tabelární částí, ale i s jinými svazky, či databázemi a poskytnutí co nejobšírnější informace, u které by byla vzhledem k použitým zdrojům jistota hodnověrnosti informace. Dotazy na vyhledávání by bylo možné i konkrétně specifikovat - například v jakých sekcích konkrétně chceme vyhledávat, hledání pouze kódů/ názvů, či ideálně fulltextové vyhledávání v kontextu - které by šlo následně využít u verze MKN-11, která by obsahovala velké množství informací o tématu i jinde než pouze v názvech. Fulltextové vyhledávání a práce $s$ autokorekcí by též napomohla $v$ případě, že uživatel nezná přesné znění onemocnění, či jen část názvu a aplikace by byla schopna dle nejpravděpodobnější shody upravit návrh výsledku vyhledávání. K uživateli by se tak dostala ve finální verzi co nejpřesnější odpověd' na hledaný dotaz v podobě konkrétního hledaného výrazu či návrhu alternativ, a zároveň i další škála informací, která by byla s hledaným pojmem propojena, či by byla získána z jiných zdrojů. Uživatel by tak při minimální námaze byl schopen získat co nejobšírnější množství informací. Dalo by se i říci, že jsme se inspirovali snahou a vytvoření české alternativy webového portálu Světové zdravotnické organizace [5], která je již nyní velmi sofistikovaná.

\section{Závěr}

Mezinárodní klasifikace nemocí je publikací, která obsahuje obrovské množství strukturovaných informací, jejichž počet a komplexita se neustále zvyšuje. $V$ dnešní době je sice velmi často využívaná, ne vždy jsou ovšem naplno využity všechny její součásti a s bližícím se príchodem nové verze MKN-11 bychom rádi tohoto zdroje informací využili pro tvorbu nástroje, který by mohl naplno využít všechny její součásti, a poskytnout veškeré v ní obsažené informace. Nástroje, který by byl zároveň uživatelsky velmi přívětivý a intuitivní, a zároveň s vysokou úrovni komplexnosti, kterého by bylo možno využít jak pro poskytování informací, tvorbu statistik, tak i usnadnění práce se zdravotnickou dokumentací a jejím vedením.

\section{Literatura}

[1.] Tudorache T., Falconer S., Nyulas C., Noy N.F., Musen M.A. (2010) Will Semantic Web Technologies Work for the Development of ICD-11?. In: Patel-Schneider P.F. et al. (eds) The Semantic Web-ISWC 2010. ISWC 2010. Lecture Notes in Computer Science, vol 6497. Springer, Berlin, Heidelberg

[2.] Jette, N., Quan, H., Hemmelgarn, B., Drösler, S., Maass, C., Moskal, L., Paoin, W., Sundararajan, V., Gao, S., Jakob, R., Ustün, B., A Ghali, W. (2010). The Development, Evolution, and Modifications of ICD-10: Challenges to the International Comparability of Morbidity Data. Medical care.

[3.] International Classification of Diseases. Dostupné z: http://www.who. int/classifications/icd/en/[online]. [cit. 2018-02-22].

[4.] Mezinárodní statistická klasifikace nemocí a pridružených zdravotních problemů. Dostupné z http://www.uzis.cz/katalog/klasifikace/ mkn [online]. [cit. 2018-02-22].

[5.] Webový portal Světové zdravotnické organizace pro práci s MKN. http://apps.who.int/classifications/icd10/browse/2016/en\#/[online]. [cit. 2018-02-22]. 


\section{Kontakt}

Michal Reimer

Fakulta biomedicínského inženýrství ČVUT

nám. Sítná 3105

27201 Kladno

E-mail: Michal.Reimer@centrum.cz 